NEWS

\title{
Obama budget backs basic science
}

\section{Climate and clean energy receive a boost but NASA's Moon mission bites the dust.}

In the first federal budget proposal to fully reflect his priorities, US President Barack Obama has signalled strong support for science and technology. His fiscal year 2011 budget request, announced on 1 February, calls for $\$ 66$ billion to be spent on non-defence research and development, a 5.9\% increase over this year's budget.

The increase is striking, given Obama's vow to freeze overall non-security discretionary spending - one part of the budget, not including mandatory programmes such as social security, over which Congress and the president have control. The proposed budget would fulfil that pledge, with all the potential political heat that implies, by cutting elsewhere.

"It's very gratifying to see science treated this way in a time of very severe budgetary constraint," says John Marburger, who served as science adviser under former president George W. Bush.

Obama has called investment in science a driver of the American economic engine. His proposal includes a modest increase for the National Institutes of Health (NIH), which apart from a one-time economic stimulus bonanza has experienced stagnant funding in recent years. And it would see strong increases for the National Science Foundation (NSF), the National Institute of Standards and Technology (NIST) and the Department of Energy's Office of Science (see Table). Bush had started to double the collective budgets of these three agencies over 10 years, and Obama's request would keep that plan on track.

Congress has the final say over what the budget numbers for 2011 will be, and it is still unclear whether lawmakers will go along with his priorities. Last year, however, Congress did award more than $\$ 21$ billion in research and development funding in the economic stimulus bill.

The new request puts a heavy emphasis on climate research and clean-energy development, allocating $\$ 2.6$ billion to the multi-agency US Global Change Research Program, for example - an increase of $21 \%$. It would tackle some long-neglected problems, including restructuring the troubled National Polar-orbiting Operational Environmental Satellite System to streamline coordination between the National Oceanic and Atmospheric Administration,

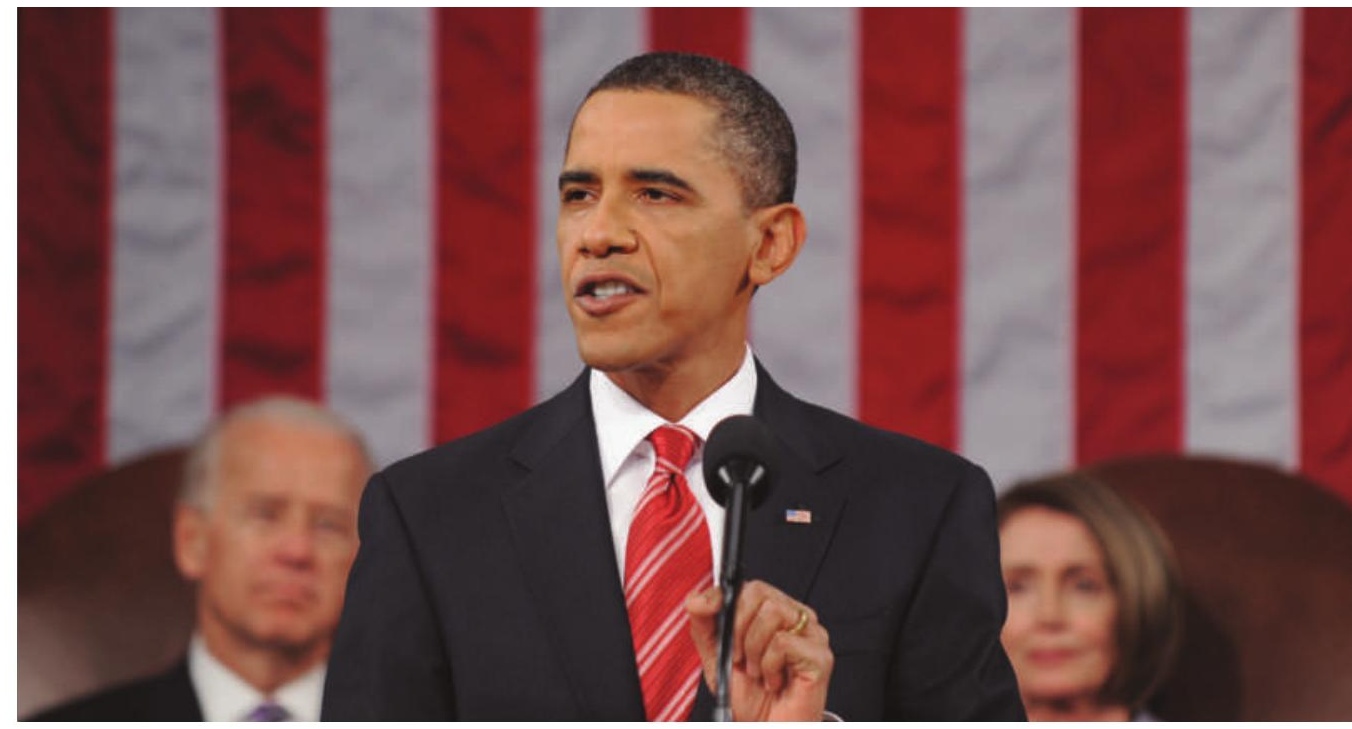

Barack Obama hinted at his spending priorities in his State of the Union address.

NASA and the defence department. Perhaps most significantly, the proposal would cancel NASA's flagship Constellation programme of rockets and capsules, which was inaugurated under Bush with the goal of returning astronauts to the Moon. That move is likely to face stiff opposition in Congress, as the programme produces many jobs in key members' districts.

Here's a closer look at what the proposals mean for key agencies.

\section{NASA}

NASA's overall budget would rise by $1.5 \%$ to $\$ 19$ billion. But in a radical shift, Obama's administration would give up a governmentdeveloped replacement for the space shuttle "The big challenge for NASA is to convince everyone that, now, they have the right plan." and would abandon the goal of returning humans to the Moon.

Constellation was deemed to be too far behind schedule and too expensive to justify adding to the $\$ 9$ billion that has already been spent on it. "We are not on a sustainable path to get back to the Moon's surface," said NASA administrator Charles Bolden in a briefing on 1 February.

Instead, NASA would spend $\$ 6$ billion over five years to stimulate the development of commercial rockets that would ferry not just cargo but also crew up to the International Space
Station. These rockets could be ready by 2016 , says the agency's deputy administrator Lori 文 Garver.

Marcia Smith, a former director of the Space Studies Board at the US National Research Council, says the shift is another "topsy turvy" change in NASA's goals. "The big challenge for NASA is to convince everyone that, now, they have the right plan," says Smith.

Bolden has vowed to leave NASA science untouched by the shifting winds in the human-exploration programme, and in 2011, the agency's science budget would grow by $11 \%$ to $\$ 5$ billion. Earth-science programmes would reap most of the gains, including more money to rebuild the Orbiting Carbon Observatory, a failed satellite that would have tracked global carbon dioxide levels. The astrophysics division saw a $2.6 \%$ decrease, which will hurt all the more because its biggest project, the James Webb Space Telescope due for launch in 2014, is vastly over budget.

Science may also benefit from the billions to be devoted to technology development in the human programme. Bolden says that $\$ 3$ billion over five years would be spent on robotic precursor missions such as a Moon rover or an unmanned factory to mine the Moon or asteroids. Smith says these missions could be similar to the Lunar Reconnaissance Orbiter (LRO), whose costs have been shared by the human programme and the science division. However, 
she notes, most scientific destinations are chosen by peer review, whereas missions such as the LRO were dictated by the policy to return humans to the Moon.

\section{National Institutes of Health}

The NIH's budget would be boosted by $\$ 1$ billion to a total of $\$ 32.1$ billion, a 3.2\% increase that matches the predicted rate of biomedical inflation.

"Of course I would wish for a more generous budget if that were possible," says Francis Collins, the agency's director. But, he says: "It could have been a lot worse if we didn't have an administration and a president who really values science."

For the NIH, the largest supporter of biomedical research in the world, the past few years have been a budgetary roller coaster. Follow1998 and 2003, the agency endured five years of effectively flat funding. Last year's economic stimulus bill brought a \$10.4-billion windfall that significantly increased the number of successful grant applicants.

Collins said that the success rates for applications would certainly fall under the proposed budget, but he could not anticipate how far

Despite the proposed funding increase, the agency estimates that it will give out 199 fewer competing research project grants than in fiscal year 2010, for a total of 9,052 new awards. But it would boost the payment levels on both new and existing multi-year awards by $2 \%$ to mitigate inflation. The budget would also raise stipends by $6 \%$ for the nearly 17,000 young scientists supported by the Ruth L. Kirschstein awards programme, which is the NIH's ing a doubling of the agency's budget between they would drop.

primary research-training programme for pre- and postdoctoral scientists.

Obama singled out two research areas for special attention: funding for autism studies would jump by $5 \%$ to $\$ 143$ million, and cancer research funding would rise by $4.4 \%$, to more than $\$ 6$ billion.

\section{Department of Energy}

The energy department's budget would go up by more than $7 \%$ to $\$ 28.4$ billion, providing significant increases for energy research and development, nuclear weapons and physical sciences.

The department's Office of Science, the nation's largest supporter of physical-sciences research, would get a $4.4 \%$ increase, to $\$ 5.1$ billion. That would include a $12 \%$ hike for basic energy research, funding for which would grow to $\$ 1.8$ billion.

Secretary Steven Chu's push to reorganize the department to answer pressing energy questions shaped three priorities in the budget proposal. It includes $\$ 300$ million for the Advanced Research Projects Agency-Energy to promote innovative high-risk research, building on $\$ 400$ million provided last year through stimulus funding; $\$ 107$ million for a new 'energy innovation hub' focusing on batteries and electricity storage; and $\$ 140$ million for a programme of small Energy Frontier Research Centers looking at new materials and basic energy research.

Chu acknowledges, however, that he must work to convince Congress to support these ideas: last year, he proposed setting up eight energy innovation hubs, but Congress provided funding for just three.

Spending on solar-energy research would

\begin{tabular}{|c|c|c|c|c|}
\hline \multicolumn{5}{|c|}{ OBAMA'S BUDGET REQUEST FOR 2011 (US\$ million) } \\
\hline Agency & 2009 (actual) & Stimulus & 2010 (enacted) & 2011 (president's request) \\
\hline National Institutes of Health & 30,396 & 10,400 & 31,089 & 32,089 \\
\hline National Science Foundation & 6,490 & 3,002 & 6,873 & 7,424 \\
\hline $\begin{array}{l}\text { Department of Energy's } \\
\text { Office of Science }\end{array}$ & 4,773 & 1,633 & 4,895 & 5,121 \\
\hline NASA & 17,782 & 1,002 & 18,724 & 19,000 \\
\hline $\begin{array}{l}\text { National Oceanic and } \\
\text { Atmospheric Administration }\end{array}$ & 4,454 & 830 & 4,853 & 5,554 \\
\hline $\begin{array}{l}\text { National Institute of Standards } \\
\text { and Technology (core funding) }\end{array}$ & 820 & 580 & 862 & 922 \\
\hline Environmental Protection Agency & 7,633 & 7,220 & 10,298 & 10,020 \\
\hline US Geological Survey & 1,044 & 140 & 1,112 & 1,133 \\
\hline $\begin{array}{l}\text { Department of Defense } \\
\text { (basic and applied research) }\end{array}$ & 6,830 & 0 & 7,204 & 6,475 \\
\hline $\begin{array}{l}\text { Department of Homeland } \\
\text { Security (science and } \\
\text { technology) }\end{array}$ & 933 & 0 & 1,006 & 1,018 \\
\hline
\end{tabular}

rise by $22 \%$ to $\$ 302$ million, and wind-energy research would jump by $53 \%$ to $\$ 123$ million with an increased focus on offshore applications. Overall funding for fossil energy would drop by $20 \%$ after a huge increase in stimulus spending; Obama also proposes ending fossilfuel tax subsidies worth $\$ 2.7$ billion annually.

Perhaps the biggest changes come in nuclear power. In addition to cancelling funding for an underground nuclear-waste repository at Yucca Mountain in Nevada, Obama wants to restructure the nuclear-energy research programme by shifting $\$ 195$ million into the development of small nuclear reactors and other advanced nuclear designs. The budget would also provide $\$ 36$ billion in loan guarantees for new nuclear power plants, adding to the $\$ 18$ billion that was authorized last year.

\section{National Science Foundation}

The NSF would see its budget rise from $\$ 6.9$ billion to $\$ 7.4$ billion. The bulk of that increase would go to the agency's core research activities, which would receive around $\$ 6$ billion. This would be shared across all of the research disciplines it funds.

The budget for building major research equipment and facilities would rise by $41 \%$, to $\$ 165$ million. More than half of that boost would go to the Ocean Observatories Initiative, a network of sensors that is intended to provide unprecedented measurements of currents and other climate-influencing factors in the oceans. The agency would also spend $\$ 20$ million to begin the construction of the National Ecological Observatory Network (NEON), another major facility that aims to monitor and forecast ecological changes at a continental scale over multiple decades. "NEON will collect data on the effects of climate change, changes in land use, and invasive species on natural resources and biodiversity," says NSF director Arden Bement.

As in last year's budget, Obama put a heavy emphasis on basic research into climate science, proposing \$766 million for research into renewable-energy technologies and environmental- and climate-system processes. To attract and educate future scientists and engineers in clean-energy fields, a new programme known as RE-ENERGYSE would provide $\$ 19$ million for up to 8,500 students pursuing clean-energy careers by 2015 . Other educational initiatives include a 'cyberlearning transforming education' programme to bring advanced learning technologies such as networked computing to students at all levels. Reported and written by Janet Fang, Eric Hand, Richard Monastersky, Jeff Tollefson, Meredith Wadman and Mitchell Waldrop. See Editorial, page 587. 